\title{
GAYA BAHASA PERBANDINGAN DALAM KUMPULAN PUISI BIARKAN JARIKU KINI YANG MENGUNGKAPKANNYA KARYA KAWE'ARKAAN
}

\author{
Gita Kumala Dewi ${ }^{1}$, Sumiharti ${ }^{2}$ \\ Program Studi Pendidikan Bahasa dan Sastra Indonesia, \\ Fakultas Keguruan dan Ilmu Pendidikan, Universitas Batanghari, \\ Jambi \\ Gitakumaladewi1995@gmail.com ${ }^{1}$ \\ harti.sumi@yahoo.com²
}

\begin{abstract}
The purpose of this research is to describe figurative language of comparison in the collection of poetry Biarkan Jariku Kini yang Mengungkapkannya by Kawe 'Arkaan which consist of three aspects, they are: proverbs, personification, and depersonification. This research uses descriptive method with content analysis. The primary data of the research is the words which contain figurative language of comparison in the collection of the poetry Biarkan Jariku Kini yang Mengungkapkannya by Kawe 'Arkaan. Meanwhile the technique of collecting data is library study. Based on the result of the analysis, it can be found that there is figurative language in the collection of poetry Biarkan Jariku Kini yang Mengungkapkannya by Kawe 'Arkaan. It has three aspects, they are provebs, personification, and depersonification. The result of the analysis shows: (1) 18 expressions of proverbs, (2) 51 expressions of personification, (3) no depersonification. The dominant of figurative language occured is personification.
\end{abstract}

Keywords: Figurative Language, Poetry

\footnotetext{
${ }^{1}$ Mahasiswa Program Studi Pendidikan Bahasa dan Sastra Indonesia, Fakultas Keguruan dan Ilmu Pendidikan, Universitas Batanghari, Jambi

${ }^{2}$ Dosen Program Studi Pendidikan Bahasa dan Sastra Indonesia, Fakultas Keguruan dan Ilmu Pendidikan, Universitas Batanghari, Jambi

Gaya Bahasa Perbandingan dalam Kumpulan Puisi Biarkan Jariku Kini yang Mengungkapkannya Karya Kawe 'Arkaan
} 


\section{PENDAHULUAN}

Suatu karya dapat dikatakan memiliki nilai sastra bila di dalamnya terdapat kesepadanan antara bentuk dan isi. Bentuk bahasanya baik, indah, dan isinya dapat menimbulkan perasaan haru dan kagum di hati pembaca. Bentuk dan isi sastra harus saling mengisi yaitu dapat menimbulkan kesan yang mendalam di hati para pembacanya sebagai perwujudan nilai-nilai karya seni. Selain itu sebuah karya sastra lahir dan bersumber dari kehidupan yang memiliki nilai. Hal inilah yang membuat sebuah karya sastra seperti novel, puisi, film dan drama dapat memberi sumbangan bagi terbentuknya nilai-nilai positif kehidupan bermasyarakatt (Rahima 2017:1).

Sebuah karya sastra baik novel, puisi maupun drama mutlak memiliki gaya bahasa, yang mencerminkan cara seorang pengarang dan penulis sastra. Gaya bahasa diungkapkan dengan cara yang khas, sehingga tujuan yang dimaksudkan dapat tercapai dengan maksimal. Gaya bahasa juga membantu pembaca untuk membedakan karya masing-masing pengarang, karena setiap pengarang memiliki cara tersendiri dalam menyampaikan karyanya.

Dalam sebuah puisi banyak ditemukan bentuk gaya bahasa. Salah satunya ialah gaya bahasa perbandingan. Gaya bahasa perbandingan ini cukup menarik untuk dibahas. Jenis gaya bahasa perbandingan memiliki bentuk yang bervariasi misalnya gaya bahasa perumpamaan, gaya bahasa personifikasi, dan gaya depersonifikasi yang terdapat dalam larik-larik puisi.

Dengan gaya bahasa perbandingan tersebut, peneliti dapat menentukan perbedaan atau pertentangan yang terdapat dalam puisi sehingga pembaca terbawa persaan sedih, senang, maupun duka ketika membaca puisi tersebut. Hal inilah yang membuat peneliti tertarik untuk meneliti gaya bahasa perbandingan

dalam kumpulan puisi Biarkan Jariku Kini yang Mengungkapkannya karya Kawe 'Arkaan. Gaya bahasa perbandingan yang digunakan memberikan warna dalam puisi, yang berkaitan dengan kata-kata kiasan, ungkapan dalam bentuk perbandingan untuk meningkatkan kesan kepada pembaca dan pendengar. Sejauh ini, masyarakat tidak mengetahui gaya bahasa apa yang terkadung di dalam puisi tersebut. Dengan adanya gaya bahasa perbandingan dalam kumpulan puisi Biarkan Jariku Kini yang Mengungkapkannya karya Kawe 'Arkaan masyarakat akan menjadi tahu tentang gaya bahasa perbandingan yang terkadung di dalam puisi tersebut.

Puisi merupakan salah satu karya sastra yang banyak mengandung makna simbolik. Struktur dalam puisi terdiri dari tanda-tanda dan simbol-simbol yang bermakna. Kegiatan simbolik yang dilakukan oleh pengarang merupakan rangkaian simbolik dalam jejaring pengalaman seorang manusia. Simbolsimbol dalam sebuah puisi sarat dengan nilai-nilai positif seperti moral, agama, sosial, dan budaya dapat berfungsi sebagai sarana pendidikan karakter (Rahima, 2017:251). Makna yang terkandung dalam tanda dan simbol dalam puisi disampaikan dalam bentuk gaya bahasa tertentu.

Salah satu puisi yang menarik untuk dikaji adalah kumpulan puisi Biarkan Jariku Kini yang Mengungkapkannya. Puisi ini menceritakan sebuah perjalanan cinta yang terhimpun dalam surat cinta terakhir. Permasalahan yang sangat kompleks memacu penyair untuk menggambarkan perasaan yang ingin diungkapkan penyair.

Kumpulan puisi Biarkan Jariku
Kini yang Mengungkapkannya
merupakan kumpulan puisi karya Kawe
'Arkaan. Kawe 'Arkaan lahir di Kuala
Tungkal, 07 Desember 1992 yang adalah

Gaya Bahasa Perbandingan dalam Kumpulan Puisi Biarkan Jariku Kini yang Mengungkapkannya Karya Kawe 'Arkaan 
alumni Pendidikan Bahasa dan Sastra Indonesia FKIP Universitas Batanghari Jambi pada Tahun 2015 dan pernah bekerja sebagai penulis pada media remaja di surat kabar harian pagi. Beberapa karnyanya berupa puisi terhimpun dalam antologi bersama, antara lain: Rumah Cinta (2015), Sajak Sang Penyair (2016), Pancasila (2016), Hijrah Jiwa (2016), Aquarium \& Delusi (2016), Baju Baru Untuk Puisi \&Hal-hal Yang Belum Kita Mengerti (2017), Diary Sosmed (2016), Puisi Kemerdekaan (2016), Puisi Nusantara (2016), Moraturium Senja (2016), Gemuruh 1001 Kuda Padang Sabana (2017), dan Merayakan Puisi (2017) dan beberapa puisinya telah terbit diberbagai media cetak.

Kumpulan puisi Biarkan Jariku yang Mengungkapkannya terbagi atas 3 bagian yaitu puisi utama, Sajak Alina, dan bonus puisi Sang Mawar yang terdiri dari 58 buah puisi diantaranya puisi utama 39 puisi, Sajak Alina 13 puisi, dan bonus puisi dari Sang Mawar 6 puisi. Penelitin ini hanya membatasi pada bagian puisi utama berjumlah 32 puisi, yang memuat gaya bahasa perbandingan perumpamaan, personifikasi, depersonifikasi.

Puisi Biarkan Jariku Kini yang Mengungkapkannya Karya Kawe 'Arkaan diciptakan oleh Alumni Program Studi Pendidikan Bahasa dan sastra Indonesia Universitas Batanghari Jambi. Selain itu, puisi tersebut memiliki keunikan tersendiri, karna gaya bahasa di dalamnya begitu cermat sehingga melahirkan kata-kata indah yang membuat pembaca hanyut dalam imajinasinya. Selain gaya bahasa, peneliti mengambil gaya bahasa perbandingan.

Gaya bahasa perbandingan dipilih untuk dianalisis dalam puisi Biarkan Jariku Kini yang Mengungkapkannya karya Kawe 'Arkaan karena gaya bahasa perbandingan merupakan salah satu gaya penuturan yang banyak dimanfaatkan dalam penulisan karya sastra khususnya pada puisi.

Berdasarkan latar belakang di atas, maka dapat diidentifikasikan masalah gaya bahasa, antara lain: gaya bahasa perbandingan yaitu: (1) gaya bahasa perumpamaan, (2) gaya bahasa metafora, (3) gaya bahasa personifikasi, (4) gaya bahasa depersonifikasi, (5) gaya bahasa alegori, (6) gaya bahasa antitesis, (7) gaya bahasa pleonasme dan tautologi, (8) gaya bahasa perifrasis, (9) gaya bahasa antisipasi (prolepsis), dan (10) gaya bahasa koreksio (epanortosis) (Damayanti, 2013 :48-50).

Berdasarkan indentisifikasi masalah di atas, maka penelitian ini difokuskan pada gaya bahasa perbandingan yang meliputi: gaya bahas perumpamaan, gaya bahasa personifikasi, dan gaya bahasa depersonifikasi dalam kumpulan puisi Biarkan Jariku Kini yang Mengungkapkannya karya Kawe 'Arkaan.

Berdasarkan fokus penelitian di atas, maka pertanyaan penelitian ini adalah sebagai berikut.

1. Bagaimanakah gaya bahasa perumpamaan dalam kumpulan puisi Biarkan Jariku Kini yang Mengungkapkannya karya Kawe 'Arkaan?

2. Bagaimanakah gaya bahasa personifikasi dalam kumpulan puisi Biarkan Jariku Kin iyang Mengungkapkannya karya Kawe 'Arkaan?

3. Bagaimanakah gaya bahasa depersonifikasi dalam kumpulan puisi Biarkan Jariku Kini yang Mengungkapkannya karya Kawe 'Arkaan?

Adapun tujuan penelitian ini adalah sebagai berikut.

1. Mendeskripsikan gaya bahasa perumpamaan dalam kumpulan puisi Biarkan Jariku Kini yang 
Mengungkapkannya Karya Kawe 'Arkaan.

2. Mendeskripsikan gaya bahasa personifikasi dalam kumpulan puisi Biarkan Jariku Kini yang Mengungkapkannya Karya Kawe 'Arkaan.

3. Mendeskripsikan gaya bahasa depersonifikasi dalam kumpulan puisi Biarkan Jariku Kini yang Mengungkapkannya Karya Kawe 'Arkaan.

Secara teoretis, hasil penelitian ini diharapkan dapat menambah khasanah penelitian dalam bidang kebahasaan dan kesastraan dan dalam pengembangan teori-teori sastra khususnya pada puisi.

Secara praktis, manfaat penelitian ini adalah sebagai berikut.

1. Meningkatkan apresiasi masyarakat terhadap karya sastra yang berbentuk puisi.

2. Memberikan pengetahuan kepada guru bahwa penelitian ini bisa dipakai sebagai salah satu bahan acuan untuk memberikan bahan ajar kepada siswa atau calon guru, khususnya tentang gaya bahasa.

3. Sebagai acuan pembaca untuk memahami gaya bahasa dalam suatu karya sastra khususnya puisi.

\section{METODE PENELITIAN}

Dalam suatu penelitian sastra ada beberapa pendekatan dalam menganalisis nya. Perbedaan pendekatan inilah yang kemudian memunculkan adanya berbagai jenis penelitian sastra (Rahima, 2017:116).

Penelitian ini termasuk jenis penelitian deskriptif kualitatif. "Jenis deskriptif dapat diartikan sebagai prosedur pemecahan masalah yang diselidiki dengan menggambarkan atau melukiskan keadaan subjek atau objek penelitian pada saat sekarang berdasarkan fakta-fakta yang tampak atau sebagaimana adanya (Siswantoro, 2010:
56)." Dengan metode deskriptif, seorang peneliti dituntut untuk memecahkan data dengan cara memberi deskripsi.

Populasi dimaksudkan sebagian dari himpunan terbesar seorang dan satuan lain yang diteliti "Populasi yaitu jumlah keseluruhan unit yang akan diselidiki karakteristik atau ciri-cirinya (Djojosuroto dkk., 2004: 93).” Populasi dalam penelitian ini adalah kumpulan puisi Biarkan Jariku Kini yang Mengungkapkannya karya Kawe 'Arkaan yang terdiri dari 58 puisi yang dibagi menjadi 3 bagian yaitu: (1) Puisi Utama, (2) Sajak Alina, (3) bonus puisi Sang Mawar.

Sampel yaitu sebagian dari populasi. "Sampel yaitu sebagian dari unit-unit yang ada dalam populasi yang ciri-ciri karakteristiknya benar-benar diselidiki (Djojosuroto dkk., 2004: 93)." Tujuan dari sampel ini adalah memperoleh keterangan mengenai objek dengan jalan hanya mengamati sebagian saja dari populasi. Sampel penelitian ini ditentukan secara purposive sampling. "Purposive sampling adalah pengambilan sampel yang disesuaikan dengan tujuan penelitian (Siswantoro, 2010: 73)." Berdasarkan penentuannya maka penulis memilih bagian 1 puisi utama yang terdiri dari 39 buah puisi.

Penelitian jenis apapun tidak terlepas dari data, karena data merupakan sesuatu yang berperan penting dalam penelitian. Penelitian sastra juga memerlukan data tetapi dalam bentuk vebal. Data verbal tersebut dapat berwujud kata, frase, atau kalimat. "Data adalah sumber informasi yang akan diseleksi sebagai bahan analisis (Siswantoro, 2010: 70)." Data dalam penelitian ini adalah kata, kalimat-kalimat serta ungkapan yang terdapat dalam kumpulan puisi Biarkan Jariku Kini yang Mengungkapkannya Karya Kawe 'Arkaan. 
Teknik pengumpulan data dalam penelitian ini menggunakan teknik studi pustaka yang difokuskan dalam menganalisis gaya bahasa perbandingan dalam kumpulan puisi Biarkan Jariku Kini yang Mengungkapkannya karya Kawe 'Arkaan.

Setelah semua data diperoleh, maka selanjutnya adalah teknik analisis data. Teknik analisis data merupakan teknik untuk menepatkan dan mendapatkan hasil sesuai tujuan yang ingin dicapai dari penelitian. "Teknik analisis data dilakukan dengan pemaparan dalam bentuk deskriptif terhadap masingmasing fungsional dan relasional (Siswantoro, 2010 :81)." Dalam penelitian ini, alaisis data dilakukan dengan langkah-langkah sebagai berikut.

1. Membaca keseluruhan isi dalam kumpulan puisi Biarkan Jariku Kini yang Mengungkapkannya karya Kawe 'Arkaan.

2. Menandai atau menggarisbawahi kata serta kalimat yang berhubungan dengan gaya bahasa perumpamaan, gaya bahasa personifikasi, gaya bahasa depersonifikasi.

3. Mengelompokkan puisi yang mengandung gaya bahasa perumpamaan, gaya bahasa personifiasi, gaya bahasa depersonifikasi ke dalam jenisnya.

4. Data yang sudah ditabulasi dan dianalisis, kemudian dideskripsikan sesuai dengan aspek-aspek penelitian yang terkandung dalam isi teks puisi.

5. Setelah dianalisis dan dideskripsikan, langkah selanjutnya yaitu dengan menyimpulkan hasil data penelitian.

\section{HASIL DAN PEMBAHASAN}

Setelah melakukan analisis terhadap 32 puisi dalam kumpulan puisi Biarkan Jariku Kini yang Mengungkapkannya karya Kawe 'Arkaan, diketahui bahwa terdapat 68 gaya bahasa perbandingan.
Penelitian ini membahas tentang gaya bahasa perbandingan yang terdiri dari gaya bahasa perumpamaan, personifikasi, dan depersonifikasi yang terdapat dalam Kumpulan Puisi Biarkan Jariku Kini yang Mengungkapkannya karya Kawe 'Arkaan. Ketiga gaya bahasa tersebut akan dideskripsikan sebagai berikut.

\section{Gaya Bahasa Perumpamaan}

Gaya bahasa perumpamaan adalah padanan kata atau simile yang berarti 'seperti'. Secara eksplisit jenis gaya bahasa ini ditandai oleh pemakaian kata: seperti, sebagai, ibarat, umpama, bak, laksana, serupa (Damayanti, 2013:48). Gaya bahasa perumpamaan dapat dilihat dalam kutipan puisi-puisi berikut.

\section{a. Puisi Apa Kabar}

Rinduku berembun seperti pada kaca jendelaku. Kulirik ia dari tempatku berteduh, apa kabarmu, mawar layuku?

(AK, $2017: 15$ )

Pada kutipan puisi Apa Kabar terdapat gaya bahasa perumpamaan Rindu berembun seperti kaca jendelaku. Kutipan puisi di atas mampu mengumpamakan rindu tersebut sangatlah besar kepada seseorang yag dirindukannya, namun itu hanya sebuah banyangan belaka. Sehingga pembaca tersenyuh dan terharu di membaca puisi tersebut.

\section{b. Puisi Jarak}

Dibatasi alamat dalam satu kota.

Seperti kisah Romeo dan Juliet.

Dibatasi derajat dan kematian.

(J, 2017 :23)

Pada kutipan puisi Jarak terdapat gaya bahasa perumpamaan Seperti kisah Romeo dan Juliet. Kutipan puisi di atas mampu mengumpamakan Romeo dan Juliet seakan pembaca mengira Romeo dan Juliet itu adalah sepasang kekasih saling sayang, dan saling cinta, setia sampai ajal menjemput.

c. Puisi $\mathrm{Mei}$

Gaya Bahasa Perbandingan dalam Kumpulan Puisi Biarkan Jariku Kini yang Mengungkapkannya Karya Kawe 'Arkaan 
Sedari dulu kau selalu begitu membisu bak mawar yang layu.

Aku harap Mei yang menyatukan rindu kita, yang disembunyikan oleh malu.

\section{(M, 2017 :26)}

Pada kutipan puisi $\mathrm{Mei}$ terdapat gaya bahasa perumpamaan kutipan Bak mawar yang layu tersebut mengumpamakan seolah-olah pembaca merasakan ada seseorang yang ingin mengungkapkan rindu, tetapi seseorang tersebut tidak bisa mengungkapkannya ibaratkan seperti bunga yang layu, bunga yang layu maksudnya ialah seperti tidak ada semangat lagi, dan rindu tersebut di sembunyikan oleh malu.

\section{d. Puisi Sajak Berandai}

Angin berhembus bagaikan cinta yang terbang tanpa sayap.

(SB, 2017 :28)

Pada kutipan puisi Sajak Berandai terdapat gaya bahasa perumpamaan kutipan Bagaikan cinta yang terbang tanpa sayap. Puisi tersebut mengumpamakan seakan pembaca merasakan angin yang berhembus tersebut bagaikan cinta yang hilang, maksudnya ialah seseorang yang lagi galau tak tahu mau di bawa kemana cinta tersebut, dan juga terbang tanpa sayap maksudnya ialah cinta tersebut pergi entah kemana.

\section{e. Puisi Belenggu Rindu}

Saat kutinggalkan kotamu, tatapan matamu begitu sendu.

Seolah berkata: "masihkah aku kan bertemu padamu?"

(BR, 2017 :29)

Pada kutipan puisi Belenggu Rindu terdapat gaya bahasa perumpamaan ungkapan Seolah berkata: "masihkah aku kan bertemu padamu?" Puisi tersebut mengumpamakan seakan pembaca merasakan kegalauan yang sangat berat di sertai rasa rindu, apakah masih ada harapan atau tidak bertemu dengan orang tersebut.

\section{f. Puisi Kepada Mawar Layuku}

Aku kini sebagai ragamu yang pergi akan masa rindu yang mencekam dalam inginku padamu.

(KML, 2017: 34)

Pada kutipan puisi Kepada Mawar Layuku terdapat gaya bahasa perumpamaan Aku kini sebagai ragamu yang pergi. Kutipan puisi tersebut mengumpamakan seakan pembaca merasakan ada raga yang hilang pergi entah kemana, raga yang hilang tersebut merasakan kerinduan yang mendalam kepada seseorang tersebut.

g. Puisi Cerita Senja

Aku adalah dirimu yang kini hilangbak raga ditelan murka bumi renta.

(CS, $2017: 36)$

Pada kutipan puisi Cerita Senja terdapat gaya bahasa perumpamaan Bak raga ditelan murka bumi renta. Kutipan puisi tersebut mengumpamakan seakan pembaca merasakan aku dan dia tersebut telah hilang seakan raga ini di telan bumi yang tua.

h. Puisi Di Kampus Hijau Itu

Aku berjalan merunduk.

Berlari seperti biasa menuju kursi tua yang sudah rusak.

(DKHI, 2017 :38)

Pada kutipan puisi Di Kampus

Hijau Itu, terdapat gaya bahasa perumpamaan kutipan Berlari seperti biasa menuju kursi tua yang sudah rusak tersebut mengumpamakan seakan pembaca merasakan ada seseorang yang berjalan merunduk, seperti kehilangan arah kemudian ia seperti berlari menuju ke kursi tua yang sudah rusak, karna ada kegalauan di dalam dirinya menanti sang pujaan hari yang jauh disana.

i. Puisi Menatap Dunia Dari Jendela Peswat Terbang

Gaya Bahasa Perbandingan dalam Kumpulan Puisi Biarkan Jariku Kini yang Mengungkapkannya Karya Kawe 'Arkaan 
Termenung selalu saja menyetubuhiku.

Bagai dua orang anak kembar siam yang selalu melekat.

(MDDJPT, 2017:41)

Pada kutipan puisiMenatap Dunia

Dari Jendela Peswat Terbanggay, terdapat bahasa perumpamaan Bagai dua orang anak kembar siam yang selalu melekat. Kutipan tersebut mengumpamakan seakan pembaca merasakan ada seseorang yang lagi termenung galau, sehingga kegalauan tersebut masuk ketubuhnya, ibaratkan bagai dua orang anak kembar siam yang selalu melekat, maksudnya ialah termenung atau kegalauan tersebut tidak mau terpisah di dalam raga dan jiwanya tersebut.

\section{j. Puisi Waktu Yang Lupa Dirindu}

Hilang dari janji-janji yang sudah terucap bak ucapan semu.

(WYLD, 2017: 44)

Pada kutipan puisi Waktu Yang Lupa Dirindu, terdapat gaya bahasa perumpamaan Sudah terucap bak ucapan semu. Kutipan tersebut mengumpamakan seakan pembaca merasakan ungkapan seseorang yang tidak dapat dipercaya oleh kekasihnya.

\section{k. Puisi Aku Mencintaimu}

Tapi sepertinya mencintaimu seakan bertanya pada Tunawicara. (AM, 2017: 45)

Pada kutipan Puisi $A k u$ Mencintaimu, terdapat gaya bahasa perumpamaan Seakan bertanya pada Tunawicara. Kutipan tersebut mengumpamakan seakan pembaca merasakan seorang yang mencintai kekasihnya, tapi kekasihnya tersebut tidak tidak mencintainya dengan tulus.

1. Puisi Puisi Yang Hilang

$\begin{array}{ll}\text { Ketika imajinasi } & \text { pergi } \\ \text { meninggalkan tempatnya. } & \\ \text { Seperti kerinduan } & \text { pergi } \\ \text { meninggalkan hatimu. } & \end{array}$

(PYH, 2017:52)

Pada kutipan puisi Puisi Yang Hilang, terdapat gaya bahasa perumpamaan Seperti kerinduan pergi meninggalkan hatimu. Kutipantersebut mengumpamakan seakan pembaca mengira ada seseorang yang setia menunggu dan ingin bertemu sama kekasihnya, tetapi kekasihnya tersebut tidak kunjung datang, dan kerinduan tersebut pergi begitu saja. Sehingga pembaca terharuh, dan terbawa perasaan akan kisah tersebut.

m. Puisi Pseudo

Aku bingung harus bagaimana menyikapi.

Cinta pseudo bak cerita di negeri dongeng.

(Pseudo, 2017:38)

Pada kutipan puisi Pseudo, terdapat gaya bahasa perumpamaan Cinta pseudo bak cerita di negeri dongeng. Kutipan tersebut mengumpamakan seakan pembaca merasakan ada seseorang yang sedang bermimpi cinta tersebut seperti di negeri dongeng, maksudnya ialah cintanya tersebut hanyalah kayalan belaka. Ungkapan puisi-puisi di atas sesuai dengan pendapat Damayanti (2013:48) yang mengatakan bahwa gaya bahasa perumpamaan merupakan padanan atau simile yang berarti seperti.

\section{Gaya Bahasa Personifikasi}

Gaya bahasa personifikasi ialah gaya bahasa yang melekatkan sifat-sifat insani pada barang atau benda yang tidak bernyawa ataupun pada ide abstrak (Damayanti, 2013:48). Gaya bahasa personifikasi dapat dilihat dalam kutipan puisi-puisi berikut.

a. Puisi Selamat Datang Cinta

Terukir mengikis kalbu mengis hati. Adakah cinta menyapa dalam keheninganku?

(SDC, $2017: 16$ )

Gaya Bahasa Perbandingan dalam Kumpulan Puisi Biarkan Jariku Kini yang Mengungkapkannya Karya Kawe 'Arkaan 
Pada kutipan puisi Selamat Datang Cinta, terdapat gaya bahasa personifikasi Adakah cinta menyapa dalam keheninganku? Puisi tersebut mampu melekatkan sifat-sifat insani pada barang atau benda yang tidak bernyawa seperti cinta dan keheningankuseakan pembaca melihat atau merasakan cinta tersebut ingin membuat seseorang itu senang, dan gembira, tetapi tidak bisa, karna kegundahan atau keheningan tersebut telah masuk ke dalam tubuh seseorang tersebut, dan merasakan galau yang mendalam.

b. Puisi Kupanggil Kau Mawar

Kupanggil kau Mawar dalam
belenggu cinta mengatip ubun
kelopak menutup kalbu.
(KKM, $2017: 17)$

Pada kutipan puisi Kupanggil Kau Mawar, terdapat gaya bahasa personifikasi kupanggil kau mawar kutipan puisi tersebut mampu melekatkan sifat-sifat insani pada barang atau benda yang tidak bernyawa seperti mawar seakan pembaca melihat mawar tersebut seperti layaknya manusia yang dapat membelenggu cinta seseorang.

c. Puisi Kupanggil Kau Mawar

Saat badai cinta datang.

Mengering jejak dalam kepak sajak yang mekar.

(KKM, 2017 :17)

Pada kutipan puisi Kupanggil

Kau Mawargaya, terdapat bahasa personifikasi Mengering jejak dalam kepak sajak yang mekar. Kutipan puisi tersebut mampu melekatkan sifat-sifat suatu benda pada ide-ide abstrak seperti mengiring jejak malam kepada sajak yang mekar seakan pembaca melihat jejak malam tersebut adalah angin yang mengirim pesan.

\section{d. Puisi Kau}

Dan aku sangat menyukai di balik kerudungmu.
Karena di balik kerudungmu tersimpan sebuah hati yang tulus.

(K, $2017: 18)$

Pada kutipan puisi Kau, terdapat gaya bahasa personifikasi Dan aku sangat menyukai di balik kerudungmu. Kutipan puisi tersebutmampu melekatkan sifat-sifat suatu benda pada ide-ide abstrak seperti kerudung seakan pembaca mengira di balik kerudung tersebut, ada sesuatu yang membuat seseorang tersebut akan senang, karena dibalik kerudung itulah tersimpan sebuah hati yang tulus, maksudnya ialah hati yang ikhlas, dan lembut.

\section{d. Puisi Aku Hanya Ingin Sendiri}

Tak apa jika aku menjadi senja.

Aku akan menunggunya.

(AHIS, 2017:19)

Pada kutipan puisi Aku Hanya Ingin Sendiri, terdapat gaya bahasa personifikasi Tak apa aku menjadi senja. Kutipan puisi tersebut mampu melekatkan sifat-sifat suatu benda pada ide-ide abstrak seperti senja seakan pembaca mengira senja tersebut adalah seseorang yang sedang menunggu kepastian yang akan datang, dan menghampiri seseorang tersebut.

e. Puisi Aku Hanya Ingin Sendiri

Sinar rembulan akan tetap datang di malam ini.

Namun sang bintang enggan menghampiri.

(AHIS, 2017: 19)

Pada kutipan puisi Aku Hanya Ingin Sendiri, terdapat gaya bahasa personifikasi Namun bintang enggan menghampiri. Kutipan puisi tersebut mampu melekatkan sifat-sifat suatu benda pada ide-ide abstrak seperti sang bintang seakan pembaca mengira sang bintang itu adalah orang yang tidak mau menghampiri seseorang yang jauh disana, dan ingin menyendiri.

f. Puisi Jarak 
Daun yang tumbuh kemudian mengering, hingga bertahan sampai akhirnya gugur.

Sebab angin yang memutuskan tangkainya pun dengan kehidupanku, rasa pada masa.

(J, 2017 :23)

Pada kutipan puisi Jarak, terdapat gaya bahasa personifikasi Sebab angin yang memutuskan tangkainya. Kutipan puisi tersebut mampu melekatkan sifat-sifat suatu benda pada ide-ide abstrak seperti angin dan tangkai pembaca merasakan seakan angin tersebut berbicara kepada daun yang tumbuh kemudian mengering, dan ingin memutuskan tangkainya.

g. Puisi Di Tepi Sungai Batanghari di Kala Malam

Di tepi sungai Batanghari kita bersulang Memecahkan secangkir teh di kala malam

(DTSBDM, 2017 :25)

Pada kutipan puisi Di Tepi Sungai Batanghari di Kala Malam, terdapat gaya bahasa personifikasi Di tepi sungai batanghari kita bersulang. Memecahkan secangkir teh di kala malam. Puisi tersebut mampu melekatkan sifat-sifat suatu benda tak bernyawa pada manusia seperti cangkir seakan pembaca mengira di tepi sungai batanghari tersebut ada dua orang kekasih yang sedang bertemu, hari kian malam dan mereka pulang.

h. Puisi Sajak Berandai

Kertas putih adalah cinta.

yang bersih tak dinodai biadab. (SB, 2017:28)

Pada kutipan puisi Sajak Berandai, terdapat gaya bahasa personifikasikutipan Kertas putih adalah cinta. Kutipan puisi tersebut mampu melekatkan sifat-sifat suatu benda pada ide-ide abstrak seperti kertas dan cinta seakan pembaca merasakan kertas itu adalah cinta cinta itu bersih sama sekali tak di nodai oleh apapun.

i. Puisi Belenggu Rindu

Akhirnya kau pergi dari
pelabuhanmu

Tak kutemukan dermagamu

Tempat singgahan kapal yang berlabuh

(BR, 2017 :29)

Pada kutipan puisi Belenggu

Rindu, terdapat gaya bahasa depersonifikasi Tak kutemukan dermagamu. Puisi tersebut mampu melekatkan sifat-sifat suatu benda tak bernyawa pada manusia seperti dermaga, seakan pembaca mengira dermaga tersebut adalah hati seseorang yang dipermainkan oleh cinta, datang dan pergi begitu saja, sehingga seseorang tersebut menjadi galau, dan rindu akan kekasihnya.

j. Puisi Nyanyian Malam

Dalam lindungan malam.

Aku bersujud pada lantai suci.

(NM, $2017: 33$ )

Pada kutipan puisi Nyanyian Malam, terdapat gaya bahasa personifikasi Aku bersujud pada lantai suci. Kutipan puisitersebut mampu melekatkan sifat-sifat suatu benda pada ide-ide abstrak seperti aku dan lantai suci seakan pembaca merasakan ada seseorang berdoa meminta kepada Allah, dan dia bersujud pada lantai, dia meminta kepada Allah, supaya cinta yang ia miliki seindah di langit surga yang menghias pada tabir angan.

k. Puisi Pagi

Ketika mentari tiba, kau enggan menegur cahaya pagi. (P, 2017 :30)

Pada kutipan puisi Pagi, terdapat gaya bahasa depersonifikasi Ketika mentari tiba, kau enggan menegur cahaya pagi. Puisi tersebut mampu melekatkan sifat-sifat suatu benda tak bernyawa pada manusia seperti mentari

Gaya Bahasa Perbandingan dalam Kumpulan Puisi Biarkan Jariku Kini yang Mengungkapkannya Karya Kawe 'Arkaan 
dan pagi. Seakan pembaca mengira pagi yang cerah telah tiba, tetapi mentari enggan menegur. Maksudnya ialah ada seseorang yang sedang sendiri menunggu kekasihnya, tak lama kemudian kekasihnya datang dan tak mau menegur seseorang tersebut.

\section{Puisi Musim}

Aku tahu kau masih di hati

Karna musim akan selalu musim semi

(Musim, 2017:32)

Pada kutipan puisi Musim, terdapat gaya bahasa depersonifikasi Karna musim akan selalu musim semi. Ungkapan puisi-puisi di atas sesuai dengan teori Damayanti (2013:48) yang mengatakan bahwa gaya bahasa personifikasi ialah gaya bahasa yang melekatkan sifat-sifat insani pada barang atau benda yang tidak bernyawa ataupun pada ide abstrak.

\section{Gaya Bahasa Depersonifikasi}

Gaya bahasa depersonifikasi ialah gaya bahasa yang melekatkan sifat-sifat suatu benda tak bernyawa pada manusia atau insan. Biasanya memanfaatkan katakata: Kalau, sekiranya, jikalau, misalkan, bila, seandainya, seumpama (Damayanti, 2013:49). Pada kumpulan puisi tidak ditemukan gaya bahasa depersonifikasi.

\section{SIMPULAN}

Berdasarkan pemaparan hasil penelitian dan pembahasan, dapat disimpulkan dari puisi utama 32 puisi Biarkan Jariku Kini yang Mengungkapkannya, ditemukan 68 gaya bahasa perbandingan. Gaya bahasa perbandingan yang paling dominan adalah gaya bahasa depersonifikasi dan yang paling sedikit adalah gaya bahasa perumpamaan. Puisi yang terangkum dalam kumpulan puisi Biarkan Jariku Kini yang Mengungkapkannya karya Kawe 'Arkaan menampilkan kata-kata yang indah, menarik dan mampu menggugah imajinasi pembaca khususnya pada gaya bahasa perumpamaan karena penyair banyak menggunakan daya imajinasinya untuk membuat gaya bahasa perbandingan yang ada di dalam puisinya tersebut.

\section{Saran}

Berdasarkan kesimpulan yang telah penulis sampaikan, berikut ini akan disampaikan beberapa saran diantaranya:

1. Bagi pembaca hasil penelitian ini diharapkan dapat menjadi salah satu alternatif dalam memahami gaya bahasa perbandingan yang terkandung dalam kumpulan puisi Biarkan Jariku Kini yang Mengungkapkannya karya Kawe 'Arkaan.

2. Bagi mahasiswa khususnya mahasiswa program studi Bahasa dan Sastra Indonesia, hasil penelitian ini hendaknya dapat dijadikan sumber pengetahuan baru mengenai gaya bahasa perbandingan.

3. Bagi penulis selanjutnya hasil penelitian ini diharapkan dapat melakukan penelitian yang lebih variasi, yakni pada kajian yang berbeda.

\section{DAFTAR PUSTAKA}

Arkaan, Kawe. (2017). Biarkan Jariku Kini yang Mengungkapkannya. Agam: Writing is Amazing (WA Publisher).

Damayanti, D. (2013). Buku Pintar Sastra Indonesia. Yogyakarta: Araska.

Djojosuroto, Kinayati, dkk. (2004). Prinsip-prinsip Dasar Penelitian

Gaya Bahasa Perbandingan dalam Kumpulan Puisi Biarkan Jariku Kini yang Mengungkapkannya Karya Kawe 'Arkaan 
Bahasa \& Sastra. Bandung: Nuansa Cendekia.

Kurniawan, A., Rahima, A., \& Amral, S. (2018). ANALISIS MAKNA SIMBOLIS DALAM KUMPULAN PUISI MALU (AKU) JADI ORANG INDONESIA KARYA TAUFIQ ISMAIL. Aksara: Jurnal Ilmiah Pendidikan Bahasa dan Sastra Indonesia, 2(1), 92-101.

Rahima, A. (2017). Interpretasi Makna Simbolik Ungkapan Tradisional Seloko Hukum Adat Melayu Jambi. Jurnal Ilmiah Universitas Batanghari Jambi, 17(1), 250-267.

Rahima, A. (2017). Literature Reception (a Conceptual Overview). Jurnal Ilmiah Dikdaya, 6(1), 1-16.

Siswantoro. (2010). Metode Penelitian Sastra (Analisis Struktur Puisi). Yogyakarta: Pustaka Pelajar. 